\title{
Paideusis
}

\section{"Ecological Thinking: The Politics of Epistemic Location" (Lorraine Code)}

\section{James Lang}

Volume 16, Number 3, 2007

URI: https://id.erudit.org/iderudit/1072492ar

DOI: https://doi.org/10.7202/1072492ar

See table of contents

Publisher(s)

Canadian Philosophy of Education Society

ISSN

0838-4517 (print)

1916-0348 (digital)

Explore this journal

Cite this review

Lang, J. (2007). Review of ["Ecological Thinking: The Politics of Epistemic Location" (Lorraine Code)]. Paideusis, 16(3), 87-92.

https://doi.org/10.7202/1072492ar viewed online.

https://apropos.erudit.org/en/users/policy-on-use/ 
Review of

\title{
Ecological Thinking: The Politics of Epistemic Location
}

by Lorraine Code, Oxford and New York: Oxford University Press, 2006

\author{
JAMES LANG \\ OISE/University of Toronto, Canada
}

\section{Overview}

With her latest book, Ecological Thinking: The politics of Epistemic Location, Lorraine Code proposes naturalized epistemology to effect nothing less than an epistemological sea change equivalent to Kant's "Copernican revolution." 1 We recall that Kant disagreed with the underlying core epistemological principle shared by his modernist contemporaries' competing rationalist and empiricist theories: that knowledge conforms to the nature of objects. Instead, in what is sometimes termed a "Copernican revolution," Kant stood this conception on its head, arguing that objects conform to our ways of knowing; that our mind, infused a priori with the faculty of reason and thus capable of accessing and applying similarly a priori "fixed laws" is actively involved in creatively synthesizing and categorizing knowledge, and is not merely a passive recipient of experience. ${ }^{2}$

Through her new epistemological framework of ecological thinking-not, as she insists, yet another epistemology in and of itself-Code envisions reconfiguring in all its aspects Kant's modernist epistemology, which she characterizes as predicated on masculinized principles of mastery (over "nature," knowledge, each other, the self), an epistemology through which the undifferentiatedinterchangeable, neutral-objective, rationally-autonomous, self-realizing individual $(S$, in $S$-knows-thatp) synthesizes universally accessible and universally justifiable knowledge $(p)$. Her revision of Kantian epistemology — what she claims has become the dominant epistemology of modern times, through which knowledge is deemed worthy of the name exclusively on its empirical-scientistic justificatory status-includes reforming the hegemonous instituted social imaginary which sustains and is sustained by Kant's master narrative and its knowers, into an instituting social imaginary of ecological thinking. Code proposes the latter as an imaginary of negotiated, rather than "given" hegemonic empiricism; of embodied, socially-morally-politically situated knowledges and knowers: interdependent, socially constructed 'second persons' rather than radically autonomous individuals who offer disembodied views from nowhere and everywhere; of knowers located "on the ground" within an eco-system, where the specificities of their ecological location suggest the necessary normatizing principles to guide them

\footnotetext{
1 Perhaps "sea change" is also an appropriate metaphor; from Shakespeare's Tempest, wherein Ariel sings of Prospero's death, "Nothing of him that doth fade/But doth suffer a sea-change/Into something rich and strange."

${ }^{2}$ See Kant, I., (1787) Critique of Pure Reason (Smith, Norman Kemp, trans. E-text version (1985) prepared for The Oxford Text Archive by Palmquist, Steven). http://www.hkbu.edu.hk/ ppp/K1texts.html\#I

(C) Copyright 2007. The author, James Lang, assigns to Paideusis the right of first publication and educational and non-profit institutions a non-exclusive license to use this document for personal use and in courses of instruction provided that the article is used in full and this copyright statement is reproduced. Any other usage is probibited without the express permission of the author.
} 
in their prescribed roles as responsible knowers who endeavour "to enact principles of ideal cohabitation"(p. 24). Importantly, Code cautions at the outset that the vision of ecological thinking does not necessarily include progress to utopian ideals, noting that "ecological thinking is as available for feeding self-serving romantic fantasies as for inspiring socially responsible transformations" (p. 6).

Such a vast canvas and ambitious goals would seem to require more than the 322 densely-packed pages Code devotes to Ecological Thinking; however, like knowledges and knowers, this book, too, is situated-in, and constitutive of her larger body of work, including: Epistemic Responsibility (1987); What Can She Know?: Feminist Theory and the Construction of Knowledge (1991); and Rhetorical Spaces: Essays on Gendered Locations, Ecological Thinking (1995), as well as key essays, such as The Perversion of Autonomy and the Subjection of Women (2000), and Feminist perspectives: Philosophical essays on method and morals (1988). Much of the conceptual structure of Ecological Thinking has been raised and reinforced in these previous works: proposing that the sex-hence, the particularity — of the knower is epistemologically significant (1991); advancing ideas of knowledge as constructed dialogically, empathetically and interpretively (1995); and, most significantly, previewing the key concepts and claims of Ecological Thinking (2000). Although familiarity with her previous works will undoubtedly benefit readers as they navigate Code's richly descriptive, theory-dense current work, she urges us to not place too much weight on her early book, Epistemic Responsibility, to which she avows Ecological Thinking is at least partially related. Code remains convinced that the former's "central regulative ideals are right," (emphasis in original). Among these she counts the ways that knowledge is bound up with public trust and the key concept of epistemic responsibility: the duty to know well; that "would-be knowers are as responsible for promoting and sustaining habitable epistemic community as they are to the evidence." Yet she now distances herself from Epistemic Responsibility's undifferentiated "generic knowers," "caught within an ethos of... liberalism," that she can no longer support (p.viii).

Instituting social imaginary, Naturalized epistemology, negotiating empiricism, ecological subjectivity, rational imagining, democratic epistemic practice - unpacking the conceptual tools Code creates, adapts and puts to work in Ecological Thinking could easily overrun my few pages here. Therefore, I will take what space I have to briefly describe just a few that are central to her claims in this book; note, however, that as she uses them, these concepts are intricately interconnected and interwoven such that they resist clear cut descriptions just as they refuse to align with Code's content in a linear fashion. Lorraine Code's work invites readers to recognize and bracket-if only on an interim basis-any un-interrogated features of the dominant scientistic-empirical epistemic social imaginary as "given," including crisp, neat boxes of ideas delineated by clear necessary and sufficient conditions.

\section{Instituting Social Imaginary}

Code borrows the concept of the "instituted social imaginary" from Castoriadis. ${ }^{3}$ Sometimes taken as "common sense," Code describes it as resembling a Kuhnian paradigm but larger in scope, not about "how knowable items in successive historical periods are spread out before the observant knower," but as being about the "often-implicit but nonetheless effective systems of images, meanings, metaphors, and interlocking explanations-expectations within which people, in specific time periods and geographical-cultural climates, enact their knowledge and subjectivities and craft their selfunderstandings" (p.29). On her account, the master narrative (empirical-positivist epistemology) represents an instituted governing social imaginary of our time, carrying within it the "structural ordering of institutions of knowledge production;" it sets the limits of what humans can know and determines the "place of knowledge in the world" (p. 30). Against this instituted imaginary, Code brings

\footnotetext{
${ }^{3}$ Code cites several works by Cornelius Castoriadis, including, "Radical Imagination and the Social Instituting Imaginary." In Retbinking Imagination: Culture and Creativity, edited by Gillian Robertson and John Rundell. London: Routledge, 1994
} 
Castoriadis's notion of the instituting imaginary to her concept of ecological thinking. Such an imaginary incorporates a capacity for continuous re-visioning, self-questioning, for imagining counter-possibilities to the instituted imaginary. In calling for a new instituting imaginary, Code aims for not merely reconfiguring the instituted imaginary, but for a re-imagining of the "whole way of thinking about the diverse positionings and responsibilities of knowing subjects, the 'nature' of knowledge" (p.61). Significantly, the act of imagining also occurs within an imaginary and requires the imaginer "..to interrupt, destabilize, that very imaginary in demonstrating the necessity, and the difficulty, of thinking beyond its confines" (p.206). In short, imagination is required to transform the imaginary.

\section{Naturalized Epistemology}

Code proposes naturalized epistemology as constitutive of an instituting social imaginary, setting it against the "mainstream" epistemological rubric, $S$-knows-that- $\not$, which, to justify knowledge "worthy of the name," necessarily reduces knowledge claims to this formulation. On this model-which has held "pride of place in mainstream twentieth-century theories of knowledge" (p.98)—the location, subjectivity and particularities of the knower are effectively regarded as impediments to knowing. Against this model, Code first brings the work of Rachel Carson and her early-and hotly contested in its day-ecological science. ${ }^{4}$ For Code this relatively new science represents the rare example of empirical work that places the scientist on the ground amid the particularities and minutiae that legitimize, rather than weaken, substantiating knowledge claims; that include the complicating and contesting details that resist reduction to simple formulation. Similarly, by situating the human knower in his or her natural ecological setting, Code establishes the epistemic terrain for a naturalized epistemology of ecological thinking.

Attempts to naturalize epistemology are not new. Code recognizes W.V.O. Quine's work on naturalizing epistemology as a noteworthy first step ${ }^{5}$, in that he argued for knowledge acquisition as trait of the biological human, rather than of a disembodied subject. However, Quine cannot escape the reductive artifice of the laboratory in studying the abstract human knower, who remains, according to Code, "a faceless, dispassionate, infinitely replicable 'individual' who knows only when he suppresses interdependence both situational and personal, along with affect, meaning and indeed all aspects of his sociality and individuality" (p.79). Against this model of knowers as "medium-sized-informationgenerating objects" (p.82), Code proposes an ecological naturalism that addresses the knower as fully embodied, socially-politically-geographically located and living interdependently, societally, with others. Neither knower nor knowledge can be separated from his or her habitus: "embodied history" and/or "a sense of one's place, with the cumulative totality of sedimented cultural and personal experiences a human being carries as he or she moves about in a social space and in relation to the power structures that shape such places"(p.28). Naturalized epistemology, on Code's description, reflects the natural ways that knowledge is produced and enacted; it is constitutive of the knower and the knower's

ecological milieu; in Code's words, “...ecological naturalism starts from the-natural—-dependence of knowledge production upon and within human and human-nonhuman interaction, in adults lives as in infancy and childhood" (p.91).

\footnotetext{
${ }^{4}$ Code cites several of Rachel Carson's works, including Silent Spring. Boston: Houghton Mifflin, 1962.

${ }^{5}$ Code cites Quine, W.V.O., Ontological Relativity and Other Essays. New York: Columbia University Press, 1969, as well as Quine's essay, "Natural Kinds," in Kornblith, Hilary, Naturalizing Epistemology. 2nd edition. Cambridge: MIT Press, 1994
} 


\section{Negotiating Empiricism}

Code wants to remove natural knowledge making from the exclusive purview of the physical and cognitive sciences, which "effectively denaturalize[s] (normatively and descriptively) extrascientific, nonmainstream, marginalized knowledge, practices, and wisdom" (p.75). Significantly, she is not discounting the usefulness of empirical evidence nor the successes of empirical science, but rather, reining in its unquestioned epistemological dominance. She points to cracks in its vaunted neutrality and objectivity, noting that facts do not usually announce themselves, that negotiations "permeate [science's] ongoing practices" from deliberating about which evidence to examine and which sources of evidence to exclude, to which testimony to accept and which to ignore. She claims that "the most urgent epistemological questions are about negotiating anew the intricacies of claiming and evaluating knowledge" (pp.100-101). A negotiating empiricism is crucial to a naturalized epistemology because "natural" in this sense includes locations, testimonies and claims for evidence that lie beyond what empirical science tends to include. A negotiating empiricism would entertain questions arising from subjective testimony and experience; it would interrogate its own "neutrality" in evaluating evidence and offering conclusions, especially those that affect human ecological habitability.

\section{Ecological Subjectivity}

An instituted social imaginary of mastery and domination figures centrally in Ecological Thinking. Challenging Kant's autonomous self-actualizing liberal individual, Code describes subjectivity as developing interpersonally, locally, societally, within the ecological milieu of the subject. She objects to the ideal of radical autonomy as an a priori truth, claiming that from birth a person is anything but autonomous, dependent on family, friends, community. Indeed, without immediate care, infants would not survive at all. She attributes the valorizing of idealized autonomy as producing the imaginary of mastery that pervades our language of human development: we conquer nature; we conceive cognitive development in terms of "mastering" knowledge and information, of "mastery over" one's physicalsocial-natural surroundings, over one's emotions, over one's body (p.134) ${ }^{6}$. The language of mastery permeates naming, normalizing and naturalizing our experiences of the world and the Other. Against this imaginary Code offers Valerie Walkerdine's claim that "all actions, all meanings, occur and indeed are made within social practices," 7 just as the subject as knower emerges within social practices so constituted by societal, interpersonal intercourse that all persons are better called 'second persons,' than 'first persons.'8 Thus Code describes development-as-knowers in terms of second-person embodied knowers, situated-habitus et al-ecologically, producing knowledges with an instituting social imaginary that not only admits of the subjective/affective in the construction of knowledge, but is enriched by it. Aided by a negotiating empiricism which allows for contesting and interrogating otherwise uncontested knowledge claims, and which respects testimonial evidence and knowledges constructed through the interplay, dialogue, and specificities of an ecological location, these knowers "know" well through their location within it. Most importantly, Code offers an instituting social imaginary of ecological thinking as providing inherent normative possibilities for knowing well and for living well together. We are morally obliged to know well so that while enacting our knowledges we enhance the habitability of our ecosystem, just as in not knowing well we tend to do the opposite.

\footnotetext{
${ }^{6}$ I would be remiss to not comment on the now-famous Seinfeld episode on masturbation, wherein the line "master of my domain" was inscribed memorably in popular parlance.

${ }^{7}$ Code cites Walkerdine's Mastery of Reason, 30.

8 Although she uses this concept elsewhere, here Code cites Baier, Annette (1985) Postures of the Mind: Essays on Mind and Morals. Minneapolis: University of Minneapolis Press, 84.
} 
Code gravitates toward examples wherein scientific practice fails to interrogate its own subjectivities and biases, such as cases of medical advocacy where she urges doctors to hear and consider the subjective, testimonial knowledge of a person's family or friend as requisite to informing the treatment prescribed. Noting the potential for harm on a larger scale, she cites the case of Nancy Olivieri, a Toronto researcher who challenged the validity of research in her institution. Until she was vindicated, she was vilified by her mostly male colleagues as insufficiently objective and presented not as another 'objective, neutral, authoritative' white-lab-coated researcher, but as essentially female. Code presents "the Olivieri affair as exemplary for developing an analysis at once politically fraught and illustrative of the complexity of establishing the public epistemic status and trustworthiness of knowers, and of scientific truths, in the real world of empirical science, vested interest, power and patronage" (p.270).

\section{Concluding Thoughts}

To date one problem many philosophers have identified with epistemologies of situated knowledges has been the difficulty in establishing normative principles. Code hopes to have met this challenge with Ecological Thinking. By locating situated knowers among and in relation to others within an epistemic ecosystem, Code creates a normatizing environment-a social-political-moral-geographical community of interrelated naturalized knowers. Just as the science of ecology is predicated on situated particularities and prescribes actions to preserve and enhance the ecology to the benefit of those who live within it, so naturalized ecological thinking finds a normative function wherein members of the epistemic ecosystem are required to know well and to enact their knowledge responsibly.

Code does not address the "ecology" of institutionalized education in Ecological Thinking, however she includes within the scope of her theory (note that she does not, herself, claim theory status for this work, but in its scope and import, the label may well be thrust upon it by others) the potential for a range of epistemic projects developed through her framework. If she can be faulted for shortcomings in this book, it may be for not addressing knowledge production in its most formalized of settings, the school. Perhaps she will address the "ecology of the classroom" in another work, or perhaps another will continue her work in this direction; for now, with her own cautions about her previous work in mind, I will suggest a jumping off point from Epistemic Responsibility, where she reminds teachers that:

persons in authority are in a position to impose their definitions upon a situation so that future action is shaped by these definitions. The point is illustrated every time a schoolchild claims to

know that something is the case because his or her teacher said so. One of the most important and difficult steps in learning who can be trusted is realizing that authority cannot create truth. (Code, 1987, 248).

\section{References}

Code, L. (1987). Epistemic responsibility. Hanover, NH: University Press of New England.

Code, L. (1988). Feminist perspectives: Philosophical essays on method and morals. In L. M. Code, Sheila; Overall, Christine (Ed.), Feminist perspectives: Philosophical essays on methods and morals (pp. 64-68). Toronto: University of Toronto Press.

Code, L. (1991). What can she know? Ithaca, NY: Cornell University Press.

Code, L. (1995). Rhetorical spaces: Essays on gendered locations. New York and London: Routledge. 
Code, L. (2000). The perversion of autonomy and the subjection of women. In C. Mackenzie, and Stoljar, Natalie (Ed.), Relational autonomy: Feminist perspectives on autonomy, agency, and the social self (pp. 181-209). Oxford: Oxford University Press.

Code, L. (2006). Ecological thinking: The politics of epistemic location. Oxford: Oxford University Press. 